\title{
ATRANKINĖS MAMOGRAFINĖS PATIKROS VYKDYMO PATIRTIS NACIONALINIAME VËŽIO INSTITUTE
}

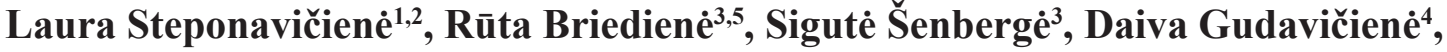 \\ Giedrè Smailytè $\dot{1}^{1,2}$ \\ ${ }^{1}$ Nacionalinio véžio instituto Vëžio epidemiologijos laboratorija, ${ }^{2}$ Vilniaus universiteto \\ Medicinos fakultetas, Sveikatos mokslu instituto Visuomenès sveikatos katedra, \\ ${ }^{3}$ Nacionalinio véžio instituto Radiologijos skyrius, ${ }^{4}$ Nacionalinio véžio instituto Krūtų chirurgijos \\ skyrius, ${ }^{5}$ Vilniaus universiteto Medicinos fakultetas, Biomedicinos mokslu institutas, Radiologijos, \\ branduolinès medicinos ir medicinos fizikos katedra
}

Raktažodžiai: krūties vėžys, mamograma, ankstyva diagnostika, atrankinè mamografinè patikra, intervaliniai navikai.

\begin{abstract}
Santrauka
Atrankinès mamografinès patikros tikslas - nustatyti krūties vėži anksti, kol jis dar nesukelia simptomų ir kai specifinis gydymas gali būti maksimaliai efektyvus. Nustatyta, kad mirtingumas vykdant atrankinę mamografinę patikrą gali sumažèti $20-35 \%$. Nors pagal atrankinę patikros programą atliktų mamogramų nauda yra akivaizdi, ne mažiau svarbu nuolatinè atrankinès mamografinès patikros programos (AMPP) vykdymo priežiūra nuo pat jos įdiegimo pradžios. Iki šiol nebuvo atlikta išsamių darbų, kuriuose būtų vertinama Lietuvoje vykdomos AMPP eiga bei efektyvumo rodikliai. Šio straipsnio tikslas apibendrinti AMPP vykdymo patirtį Nacionaliniame vėžio institute (NVI), kaip viename didžiausių pagal AMPP atliekančių mamogramas ir jų vertinimo paslaugas teikiančių centrų, bei apibūdinti pagrindinius šiuo metu vykdomos AMPP rodiklius, identifikuoti dažniausiai pasitaikančias problemas. Šio tyrimo metu atlikta retrospektyvinè duomenų analizè. Vertinti 2006-2016 metais NVI pagal AMPP atliktų mamogramų duomenys. Tyrimo metu vertinta mamogramų atlikimo ir vertinimo dinamika, atliktų papildomų tyrimų skaičius, nustatytų piktybinių navikų skaičius, pasiskirstymas pagal stadiją. Atskirai analizuoti intervaliniai navikai. Mūsų atlikta NVI sukauptų duomenų analizė parodè, kad atrankinè mamografinè patikra ne visada naudojama pagal paskirti - pasitikrinti pagal AMPP neretai siųstos gydytos dèl krūties vėžio ar akivaiz-
\end{abstract}

džių krūties simptomų turinčios moterys. Vykdant programą NVI net $19 \%$ navikų nustatyti pažengusios stadijos ir tik $46 \%$ pirmos stadijos, kas neatitinka programos vykdymo rekomendacijų.

\section{Ivadas}

Lietuvoje, kaip ir visame pasaulyje, krūties vėžys yra dažniausia piktybinè moterų liga. Šis vežzys yra ir dažniausia mirties priežastis tarp moterų mirčių dèl piktybinių navikų.

Siekiant sumažinti mirtingumą nuo krūties vėžio, reikia užtikrinti ankstyvą diagnostiką ir taikyti efektyvų gydymą. Vienas iš būdų, padedančių nustatyti ankstyvų stadijų krūties vė̌zi, yra atrankinè mamografinė patikra, kurioje kviečiamos dalyvauti tam tikrų amžiaus grupių moterys, neturinčios krūties véžio simptomų ir požymių. Atrankinès mamografinès patikros tikslas - nustatyti krūties vėži anksti, kol jis dar nesukelia simptomų ir kai specifinis gydymas gali būti maksimaliai efektyvus [1]. Atrankinių mamografinių patikrų nauda įrodyta atsitiktinių imčių tyrimais bei jau vykdomų populiacinių atrankinių patikros programų rezultatais. $\mathrm{Nu}-$ statyta, kad mirtingumas vykdant atrankinę mamografinę patikrą gali sumažèti 20-35 \% [2].

Jau 9-ajame dešimtmetyje buvo suprasta, kad atrankinès patikros programos turi būti vykdomos organizuotai. Nors pagal atrankinę patikros programą atliktų mamogramų nauda ir akivaizdi, ne mažiau svarbu nuolatinè atrankinès mamografinès patikros programos vykdymo priežiūra nuo pat jos idiegimo pradžios [3]. Apibendrinus daugelio klinikinių tyrimų duomenis bei ịvairių šalių patirtị vykdant atrankinę mamografinę patikrą, buvo sukurtos ir paskelbtos išsamios multidisciplininès rekomendacijos, kuriose nurodomos priemonès, galinčios padèti užtikrinti vykdomos programos kokybę (toliau - ES rekomendacijos) [4]. Šiame dokumente 
labai išsamiai aptariama atrankinès mamografinès patikros programos eiga, kokios būtinos sąlygos siekiant užtikrinti, kad programa būtų vykdoma maksimaliai efektyviai. Aptarti fiziniai ir techniniai mamogramų atlikimo aspektai, radiologų darbo kokybę užtikrinančios priemonès, mamogramų vertinimo aspektai. Daug dèmesio skiriama patologų bei chirurgu darbo kokybei vertinti. Aptarti multidisciplininiai krūties vėžio diagnostikos aspektai, reikalavimai specializuotiems krūties vėžio centrams. Atskiros dalys skirtos programos vykdymo duomenims kaupti ir vertinti, specialistams mokyti, informacijai apie profilaktinę programą teikti, etiniams aspektams. Kiekvienoje rekomendacijų dalyje labai aiškiai nurodomi rodikliai (jų minimalios bei pageidautinos reikšmès), kurių stebėsena užtikrina sklandžią programos eigą ir kokybę bei leidžia tikètis, kad tokia programa bus efektyvi, t.y. bus pasiektas mirtingumo nuo krūties vėžio sumažejjimas.

Lietuvoje Atrankinès mamografinès patikros programa (AMPP) vykdoma nuo 2005 metų spalio mènesio. Pagal sveikatos apsaugos ministro įsakymą dèl programos paslaugų vykdymo metodikos Lietuvoje yra vertinamas tik pakviestu dalyvauti programoje moterų skaičius bei atliktų ir ịvertintų mamogramų skaičius. Šie rodikliai yra svarbūs, tačiau pagal Europos Sajungos (ES) rekomendacijas nepakankami siekiant įvertinti programos eigą ir efektyvumą. Lietuvoje nèra sukurta AMPP registro, nors tai irgi aiškiai rekomenduojama siekiant užtikrinti programos kokybę $[5,6]$. Dél šios priežasties programos efektyvumo vertinimas šalies mastu nėra įmanomas. Iki šiol nebuvo atlikta išsamių darbų, kuriuose būtų vertinama Lietuvoje vykdomos AMPP eiga bei efektyvumo rodikliai.

Šio straipsnio tikslas - apibendrinti AMPP vykdymo patirtị Nacionaliniame véžio institute (NVI), kaip viename didžiausių pagal AMPP mamogramas atliekančiu ir vertinimo paslaugas teikiančių centrų, bei apibūdinti pagrindinius šiuo metu vykdomos AMPP rodiklius, identifikuoti dažniausiai pasitaikančias problemas.

\section{Objektas ir metodai}

Atrankinė mamografinė patikra Lietuvoje. AMPP apmokejjimo tvarka patvirtinta 2005 metais. Pagal Lietuvos Respublikos sveikatos ministro 2005-09-23 d. îsakymą Nr. V-729, „Dèl atrankinès mamografinès patikros dèl krūties vèžio finansavimo programos patvirtinimo" [7] teikiamos trijų kategorijų prevencinès paslaugos: informavimo dèl krūties piktybinių navikų profilaktikos; mamogramų atlikimo; mamogramų vertinimo.

Lietuvoje pagal AMPP mamografija atliekama kas 2 metai 50-69 metų moterims. 2016 metų sausio mènesį tikslinès populiacijos moterų buvo 451 tūkstantis. Teritorinès ligonių kasų (TLK) duomenimis, ištirtų tikslinès populiacijos moterų skaičius nuolatos didèja. Šis skaičius padidèjo nuo 47440 moteru 2006 metais iki 96593 moterų 2015 metais [8]. Pagal patvirtintą metodiką informaciją apie vykdomą atrankinę patikrą bei siuntimą tyrimui atlikti pacientes gauna iš šeimos gydytojo. Gavusios siuntimą moterys vyksta ị sertifikuotą centrą, kur atliekama ir įvertinama mamograma. Mamogramos atliekamos dviem kryptimis (kraniokaudaline bei mediolateraline šonine). Mamogramos gali būti tiek filminès, tiek skaitmenizuotos ar visiškai skaitmeninès. Atliktos mamogramos vertinamos dviejų nepriklausomų radiologų pagal BIRAD sistemą (angl. Breast Imaging-Reporting and Data System), krūties audinio tankumui ịvertinti taikoma ACR (angl. American College of Radiologists) sistema [9]. Atsakymas per 2 savaites išsiunčiamas siuntimą išrašiusiam šeimos gydytojui. Programos vykdymo pradžioje užregistruota 19 sertifikuotų centrų, 2016 metais tokių centrų užregistruota 31. Kai kurie centrai teikia tik mamogramų atlikimo paslaugą, kiti ir atlikimo, ir vertinimo paslaugas. Tik 5 centrai Lietuvoje atlieka ir tolesnį rastų pakitimų ištyrimą. Taip pat juose galimas ir specializuotas gydymas. Papildomas kvietimas ị specializuotus centrus dažniausiai vykdomas, kai nesutampa dviejų radiologų nuomoné arba kai randama įtartinų pakitimų. Tik specializuotuose centruose atliekamos tokios procedūros kaip įtartino židinio padidinimas, mamograma naudojant papildomą krūties kompresiją, krūties tomosintezè, ultragarsinis tyrimas, storos adatos ar vakuuminè biopsija bei krūties magnetinio rezonanso tomografija (MRT) arba ekscizinè biopsija.

Programos paslaugų vykdymo metodika reglamentuota LR sveikatos ministro 2004-12-10 d. įsakyme Nr. V-901 „Dèl atrankinès moterų mamografinès patikros programos atlikimo metodikos patvirtinimo" [10]. Pagal šį ịsakymą atliekamas tik kelių rodiklių vertinimas: pakviestų dalyvauti programoje moterų skaičius, atliktų ir įvertintų mamogramų skaičius bei programos finansavimas.

Atrankinė mamografinė patikra Nacionaliniame vèžio institute. Mamogramos atlikimas ir vertinimas - vieni svarbiausių AMPP komponentų. NVI šioje programoje dalyvauja kaip mamogramų atlikimo ir vertinimo centras. Paslaugos pradètos teikti nuo 2005 metų - iš karto paskelbus ministro i̇sakymą. Nuo pat programos vykdymo pradžios NVI, kaip rodo TLK ataskaitos, pirmauja visoje Lietuvoje pagal mamogramų atlikimo ir vertinimo skaičių vykdant AMPP. NVI atliekama ir įvertinama beveik $9 \%$ visų Lietuvoje pagal programą atliekamų mamogramų. AMPP vykdymo pradžioje buvo atliekamos filminès mamogramos. Nuo 2009 metu atliekamos skaitmenizuotos ir skaitmeninès mamogramos. Tačiau visiškai skaitmeninè mamograma atliekama tik diagnostikos tikslais. Šiuo metu NVI dirba 9 patyrę radiologai, turintys ne mažesnę nei 2 metų patirtį, kurie vertina mamo- 
gramas. Taip pat dirba 10 specialiai paruoštų dalyvauti AMPP radiologijos technologų. NVI veikia ir kaip specializuotas krūties patologijos ištyrimo ir gydymo centras. NVI įmanomos ir atliekamos visos procedūros, kurios reikalingos ịtartiniems pakitimams patikslinti: įtartino židinio mamogramoje padidinimas, mamograma naudojant papildomą kompresiją, krūties tomosinteze, ultragarsinis tyrimas, storos adatos ir vakuuminè biopsija, krūtų MRT ir ekscizinè biopsija. Nuo 2000 metų NVI yra galimybè atlikti rentgenu kontroliuojamą stereotaksinę įtartinų pakitimų (dažniausiai piktybinio tipo mikrokalcinatų) biopsiją. İranga tomosintezei įsigyta ir naudojama nuo 2013 metų. Vakuuminè biopsija atliekama nuo 2016 metu, 2011 metais įrengtas atskiras ultragarsinio tyrimo kabinetas, kur mamogramose matomi pokyčiai koreliuojami su ultragarsiniu vaizdu. Tai iggalina dar tiksliau ịvertinti pakitimus. Labai svarbu, kad šias procedūras - mamogramų vertinimą ir ultragarsinį tyrimą - atlieka tas pats radiologas.

Moterys, kurioms nustatomi ịtartini dèl véžio pakitimai (BIRADS 4) ar labai ịtartini dèl vèžio pakitimai (BIRADS 5), aktyviai kviečiamos ị NVI, kad joms būtų atlikti papildomi tyrimai siekiant patvirtinti arba paneigti krūties véžio diagnozę. Atvyksta didžioji dauguma pakviestų moterų. Ištyrimas dažniausiai atliekamas per 1-2 savaites. Pakviestoms moterims papildomai atliekamos visos reikalingos procedūros ir, patvirtinus vėžio diagnozę, jos siunčiamos gauti reikalingą gydymą. Nuo 2013 metų visų moterų, kurioms patvirtinta krūties véžio diagnozé, gydymas aptariamas krūties véžio multidisciplininejje komisijoje. Multidisciplininėje komisijoje dalyvauja krūtų ligų specialistas, chirurgas, radiologas, patologas, radioterapeutas, chemoterapeutas bei genetikas. Esant reikalui kviečiami kitų specialybių gydytojai.

Piktybinio naviko diagnozès nepatvirtinus, moteriai duodamas atsakymas, kuriame pateikiamos rekomendacijos dèl tolesnès jos priežiūros. Nuo 2011 metų pradètos aktyviai kviesti ir moterys, kurioms reikalingas papildomas ištyrimas (mamogramų ịvertinimas - BIRADS 0) siekiant, kad ištyrimas būtų atliktas greičiau ir efektyviau. Toks sprendimas buvo priimtas pastebejjus, kad šios moterys neretai ilgai užtrunka, kol gauna atsakymą iš šeimos gydytojo ir kol tenka laukti eilèje, kad galètų užsiregistruoti gauti onkologo konsultaciją. Jeigu radiologai pagal AMPP atliktas mamogramas ịvertino kaip BIRADS 0, 4 arba 5, tokios mamogramos sulaikomos centre, moterų duomenys perduodami atsakingai slaugytojai, kuri per savaitę susisiekia su moterimi, informuoja ją, kad reikalingas papildomas ištyrimas, bei suderina su ja patogų atvykimo laiką.

NVI visi profilaktinę mamogramą atlikusių moterų duomenys - mamogramų atlikimo data, dviejų radiologų vertinimo rezultatai bei rekomendacijos - kaupiami specialioje informacinejje sistemoje. Jei moteris buvo kviesta atlikti papildomų tyrimų, šioje sistemoje taip pat kaupiami duomenys apie papildomo atvykimo laiką, atliktus tyrimus bei nustatytą diagnozę.

Duomenų analizè. Šio tyrimo metu atlikta retrospektyvinè duomenų analizè. Vertinti 2006-2016 metais NVI pagal AMPP atliktų mamogramų duomenys. NVI pagal AMPP atliktų ir vertintų mamogramų duomenis, papildomų tyrimų rezultatai, nustatyto naviko diagnozè bei stadija gauti iš informacinès NVI sistemos. Papildomi duomenys apie siuntimus atlikti mamografinį tyrimą pagal AMPP, moters skundus ir anksčiau atliktus tyrimus gauti iš asmens ambulatorinès priežiūros kortelių. Duomenys apie anksčiau nustatytą piktybinio krūties naviko (TLK kodas C50) arba karcinomos in situ (TLK kodas D05) diagnozę ir diagnozès datą patikslinti remiantis Lietuvos vėžio registro duomenimis.

Tyrimo metu vertinta mamogramų atlikimo ir vertinimo dinamika 2006-2016 metų laikotarpiu, atliktų papildomų tyrimų skaičius, nustatytų piktybinių navikų skaičius, pasiskirstymas pagal stadiją.

Atskirai analizuoti intervaliniai navikai. Intervaliniais navikais laikyti piktybiniai navikai, nustatyti 0-730 dienų laikotarpiu (vieno patikros ciklo laikotarpis) po mamogramos atlikimo, jei mamogramoje nepamatyta jokių pokyčiu arba pastebèti pokyčiai vertinti kaip gerybiniai arba galbūt gerybiniai (BIRADS 1, 2 ir 3). Jų dažnis skaičiuotas pagal Andersen su bendraautoriais pasiūlytą metodiką [11]. Atrinkus intervalinius navikus, vertintas jų skaičius, stadija, ryšys su BIRADS kategorija bei krūties audinio tankumu. Netankaus audinio krūtimis laikytos krūtys, jei pagal ACR kategoriją nustatyta ACR1 ir ACR2. Tankaus audinio, jei nustatyta ACR3 ir ACR4.

\section{Rezultatai}

Mamogramų atlikimo dinamika. Kaip jau minèta, Lietuvoje nuo AMPP vykdymo pradžios ištirtų moterų skaičius nuosekliai dideja. 2006-2016 m. NVI pagal AMPP ištirtų moterų skaičius pateiktas 1 pav.

NVI pagal AMPP ištirtų moterų skaičius kasmet stabiliai didejja ir išaugo nuo 2074 moterų 2006 metais iki 9413 moterų 2016 metais. Kasmet NVI ištiriama vidutiniškai 8,5 $\%$ visų Lietuvoje ištiriamų moterų. NVI ištirtų moterų pasiskirstymas pagal amžių pateiktas 2 pav.

Vertinimai pagal BIRAD sistemą. İvertinimų pagal BIRAD sistemą dinamika pateikta 1 lenteleje.

Vertinimu santykis pagal BIRADS 1,2 ir 5 kategorijas tyrimo laikotarpiu nesikeite. Ivvertinimo pagal šias kategorijas procentas stabilus viso laikotarpio metu. Ženkliausiai keitèsi vertinimas pagal BIRADS 0 kategoriją. Vertinant mamogramas ši kategorija pradèta naudoti nuo 2009 metų ir tokių vertinimų nuosekliai daugèjo. Tačiau lygiagrečiai mažèjo 
vertinimu pagal BIRADS 4 ir 3 kategorijas, kas atspindi, kad dalis vertinimų buvo perkelta ị BIRADS 0 kategoriją, o tai reiškia, jog galutinis vertinimas duodamas tik atlikus papildomus tyrimus. Vertinant dèl šios kategorijos atliktus papildomus tyrimus, nenustatyta nè vieno atvejo, kad mamogramą būtų reikejję kartoti dèl techninių priežasčių (nepakankama kompresija ir pan.), kas rodo aukštą NVI radiologijos technologų kvalifikaciją ir pasiruošimą darbui.

Sujungus informacinès sistemos apie mamogramos pagal AMPP atlikimo datą ir Lietuvos vėžio registro duomenis apie nustatyto piktybinio krūties naviko diagnozę ir diagnozès nustatymo datą, buvo rastos net 62 moterys, kurios tiriamuoju laikotarpiu dalyvavo AMPP, nors jų anamnezejje jau buvo krūties věžys ir buvo taikytas gydymas nuo jo. Identifikuotos 53 moterys, kurių diagnozè invazinè karcinoma, bei 9

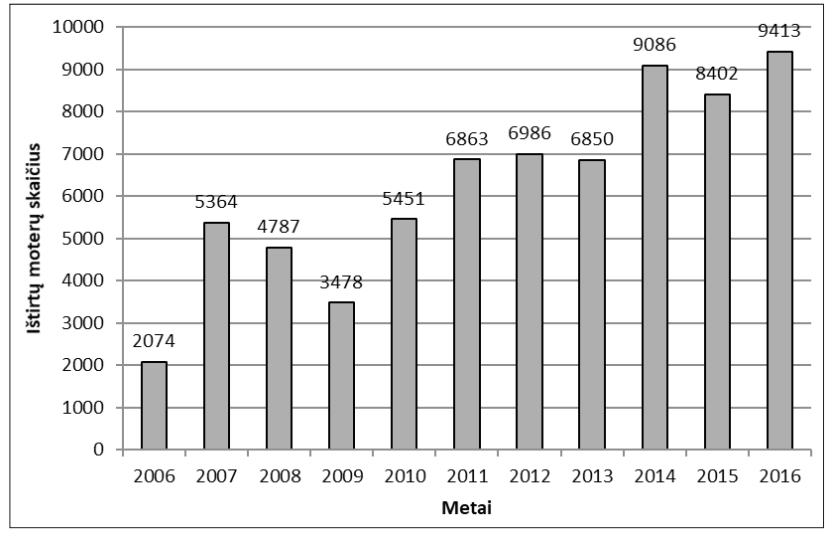

1 pav. NVI pagal AMPP ištirtų moterų skaičius 2006-2016 metais moterys, kurių diagnozė karcinoma in situ. Šios moterys nors kartą po naviko nustatymo tikrinosi pagal AMPP. Iš jų 5 moterys mamogramą pagal AMPP atliko po 2 kartus, 1 moteris 3 kartus, 2 moterys 4 kartus ir 1 moteris net 5 kartus.

Krūties navikai, nustatyti vykdant AMPP. Vykdant AMPP 2006-2016 metų laikotarpiu NVI buvo nustatyti 54 duktalinès karcinomos in situ (DCIS) arba lobulinės karcinomos in situ (LCIS) atvejai ir 441 invazinio krūties vėžio atvejis. Nustatyto invazinio vėžio atvejų skaičiaus pasiskirstymas pagal radiologų vertinimą naudojant BIRADS kategorijas pateikiamas 2 lentelejje.

Nagrinejjant šių AMPP vykdymo metu aptiktų navikų pasiskirstymą pagal stadijas, paaiškejjo, kad daugiausia navikų nustatyta ankstyvų stadijų (I ir II stadijos). Duomenys pateikti 3 lenteleje.

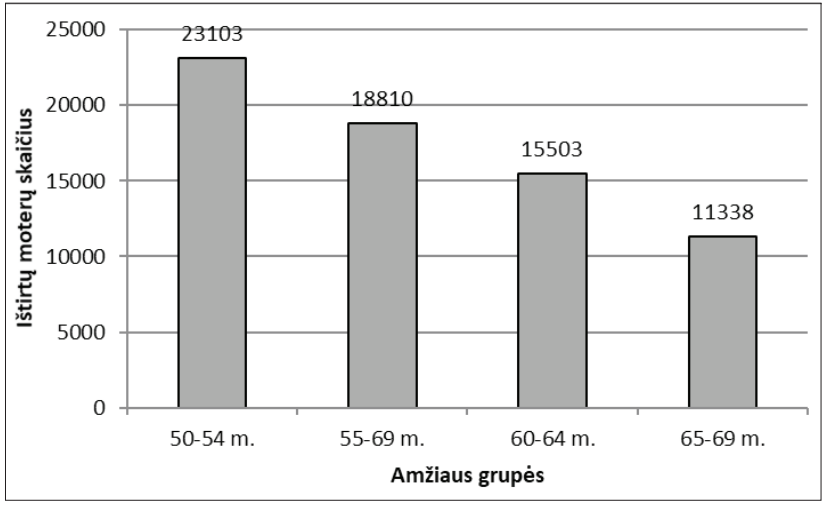

2 pav. NVI 2006-2016 metais pagal AMPP ištirtų moterų pasiskirstymas pagal amžių

1 lentelè. Mamogramų vertinimų pasiskirstymas pagal BIRADS kategorijas 2006-2016 metais

\begin{tabular}{|c|c|c|c|c|c|c|c|c|c|c|c|c|c|}
\hline \multirow[t]{2}{*}{ Metai } & \multirow[t]{2}{*}{ Iš viso } & \multicolumn{2}{|c|}{ BIRADS 0} & \multicolumn{2}{|c|}{ BIRADS 1} & \multicolumn{2}{|c|}{ BIRADS 2} & \multicolumn{2}{|c|}{$\begin{array}{c}\text { BIRADS } \\
\mathbf{3}\end{array}$} & \multicolumn{2}{|c|}{$\begin{array}{c}\text { BIRADS } \\
4\end{array}$} & \multicolumn{2}{|c|}{ BIRADS 5} \\
\hline & & $\mathrm{N}$ & $\%$ & $\mathrm{~N}$ & $\%$ & $\mathrm{~N}$ & $\%$ & $\mathrm{~N}$ & $\%$ & $\mathrm{~N}$ & $\%$ & $\mathrm{~N}$ & $\%$ \\
\hline 2006 & 2074 & 0 & 0,0 & 1490 & 71,8 & 358 & 17,3 & 185 & 8,9 & 33 & 1,6 & 0 & 0,4 \\
\hline 2007 & 5364 & 0 & 0,0 & 4202 & 78,3 & 765 & 14,3 & 308 & 5,7 & 72 & 1,3 & 17 & 0,3 \\
\hline 2008 & 4787 & 1 & 0,0 & 3874 & 80,9 & \begin{tabular}{|l|l|}
607 \\
\end{tabular} & 12,7 & 257 & 5,4 & 38 & 0,8 & 10 & 0,2 \\
\hline 2009 & 78 & 65 & 1,9 & 711 & 78,0 & 527 & 15,2 & 143 & 4,1 & 16 & 0,5 & 16 & 0,5 \\
\hline 201 & 81 & 206 & 3,8 & 4015 & 73,7 & 963 & 17,7 & 186 & 3,4 & 62 & 1,1 & 9 & 0,4 \\
\hline 2011 & 6863 & 264 & 3,9 & 5192 & 75,7 & 1154 & 16,8 & 193 & 2,8 & 36 & 0,5 & 24 & 0,4 \\
\hline 2012 & 6986 & 208 & 3,0 & 5328 & 76,3 & 1137 & 16,3 & 247 & 3,5 & 32 & 0,5 & 34 & 0,5 \\
\hline 2013 & 50 & 304 & 4,4 & 4987 & 72,8 & 1255 & 18,3 & 233 & 3,4 & 40 & $\overline{0,6}$ & 31 & 0,5 \\
\hline 2014 & 9086 & 270 & 3,0 & 7096 & 78,1 & 1420 & 15,6 & 235 & 2,6 & 34 & 0,4 & 31 & 0,3 \\
\hline 2015 & 8402 & 340 & 4,0 & 6260 & 74,5 & 1488 & 17,7 & 251 & 3,0 & 19 & 0,2 & 44 & 0,5 \\
\hline 2016 & \begin{tabular}{|l|l}
9413 \\
\end{tabular} & 358 & 3,8 & 7181 & 76,3 & 1538 & 16,3 & 270 & 2,9 & 33 & 0,4 & 33 & 0,4 \\
\hline
\end{tabular}


Iš 441 krūties vėžio atvejo, nustatyto AMPP vykdymo metu, $70(15,9 \%$ ) navikų buvo pažengusios stadijos ir net 14 moterų turèjo atokiųjų metastazių.

Intervaliniai navikai. Jei mamogramoje nerasta jokių pokyčių arba rasti pokyčiai vertinti kaip gerybiniai ar galbūt gerybiniai (BIRADS 1, 2 ir 3) ir piktybinio naviko diagnozė nustatyta 0-730 dienų laikotarpiu po mamogramos atlikimo, tai šie navikai laikyti intervaliniais. Mūsų tyrimo laikotarpiu nustatyta 16 DCIS/LCIS atvejų bei 105 intervalinio invazinio krūties věžio atvejai. Iš jų 41 nustatytas po ịvertinimo BIRADS 1, 26-BIRADS 2 ir 38 kai radiologo vertinimas buvo BIRADS 3. Apskaičiuotas intervalinių navikų dažnis -0,19.

Kadangi nustatyta, jog intervalinių navikų skaičius būna didesnis antroje patikros ciklo pusejje (jei mamograma atliekama kas 2 metus, tai vertinamas navikų skaičius pirmais ir antrais metais), atlikta intervalinių navikų skaičiaus analizè pirmais ir antrais patikros ciklo metais. Nustatyta, kad pirmais metais po atliktos mamogramos diagnozuoti 45 intervaliniai krūties vèžio atvejai, antrais metais tokių atvejų buvo 60 . Vertinant pasiskirstymą pagal stadijas, daugiausia intervalinių navikų nustatyta I stadijos (46\%). Intervalinių navikų pasiskirstymas pagal stadijas pateiktas 4 lentelejje.

Atlikus intervalinių navikų vertinimą pagal krūties audinio tankị, ryšio tarp audinio tankumo ir intervalinių navikų dažnio nenustatyta.

\section{Diskusija}

Vienas labai svarbių AMPP vertinimo kriterijų yra patikros jautrumas. Didelis patikros jautrumas yra būtina sąlyga pagrindiniam patikros tikslui pasiekti - sumažinti mirtingumą dẻl krūties véžio, nustatant ankstyvus pakitimus. Tai reiškia, kad tikrinantis pagal AMPP neturi būti daug in-

2 lentelė. Mamogramų ịvertinimų pasiskirstymas pagal BIRADS kategorijas ir nustatytų invazinio vėžio atvejų skaičius

\begin{tabular}{|l|c|c|c|}
\hline $\begin{array}{l}\text { BIRADS } \\
\text { kategorija }\end{array}$ & $\begin{array}{c}\text { Ivertinimų } \\
\text { skaičius }\end{array}$ & $\begin{array}{c}\text { Nustatyto invazinio } \\
\text { véžio atvejų skaičius }\end{array}$ & $\begin{array}{c}\text { Procentas } \\
\text { nuo ịverti- } \\
\text { nimo }\end{array}$ \\
\hline BIRADS 0 & 2016 & 94 & 4,7 \\
\hline BIRADS 4 & 415 & 116 & 28,0 \\
\hline BIRADS 5 & 267 & 231 & 86,5 \\
\hline
\end{tabular}

3 lentelè. Programos metu nustatytų navikų pasiskirstymas pagal stadijas

\begin{tabular}{|l|c|c|}
\hline Stadija & Atvejų skaičius & $\begin{array}{c}\text { Procentas nuo nustatyto } \\
\text { navikų skaičiaus }\end{array}$ \\
\hline I & 217 & 49,2 \\
\hline II & 140 & 31,7 \\
\hline III & 70 & 15,9 \\
\hline IV & 14 & 3,2 \\
\hline
\end{tabular}

tervalinių navikų. Pradejjus vykdyti AMPP ir atliekant jos vertinimą, imtos išskirti trys krūties vèžio formos: AMPP metu nustatytas vėžys, intervalinis vėžys ir simptominis vèžys. Pagal NHSBSP (angl. National Health System Breast Screening Programme) ir Europos rekomendacijų apibrèžimą intervaliniai navikai yra tie krūtų navikai, kurie diagnozuoti laikotarpiu tarp planuotų patikros vizitų moterims, kurioms buvo atlikta mamograma pagal AMPP ir duotas atsakymas, kad krūties vėžio požymių nèra, t. y. prieš tai buvęs patikros epizodas įvertintas kaip neigiamas $[4,12]$. Intervaliniai navikai yra neišvengiami vykdant AMPP, bet turi būti siekiama kuo mažesnio jų skaičiaus.

Yra duomenų, kad moterų, reguliariai dalyvaujančių patikros programoje, apie 28-33 \% naviku pasireiškia kaip intervaliniai. Tornberg su bendraautoriais atliko jungtinę 6 Europos valstybiu atrankinès mamografinès patikros programų analizę, siekdami ịvertinti intervalinių navikų dažnị. Tyrime buvo nustatyta, kad intervalinių navikų skaičius 10 000 patikrintų 50-69 metų amžiaus moterų, kurioms patikra atlikta kas 24 mèn., svyravo nuo 8,4 iki 21,3 [13]. Intervalinių navikų dažnis buvo skaičiuotas pagal ES rekomendacijas:

Proporcinis intervalinių navikų dažnis $=$

intervalinių navikų dažnis tikètinas bazinis sergamumas nesant atrankinès patikros

Šiame tyrime apskaičiuotas intervalinių navikų dažnis svyravo nuo 0,26 iki 0,67. Tačiau toks metodas yra gana sudètingas ir kai kurių autorių kritikuojamas, kadangi atrankinè mamografinè patikra vykdoma jau daug metų daugelyje šalių ir tikètiną bazinị sergamumą, jei tokia programa nevykdoma, sunku apskaičiuoti. Tyrejai iš Danijos [11] pasiūlè paprastesnę intervalinių navikų dažnio apskaičiavimo formulę:

Intervalinių navikų intervaliniai navikai intervaliniai navikai + patikros metu nustatyti navikai

Šie tyrejjai taip pat atliko ir minèto Tornberg tyrimo rezultatų perskaičiavimą pagal savo metodiką. Perskaičiuoti intervalinių navikų dažniai svyravo tarp 0,22-0,37. Mūsų tyrimo metu pagal šią formulę nustatytas intervalinių navikų dažnis siekia 0,19 . Šis dažnis, palyginti su kitų šalių duomenimis,

4 lentelè. Intervalinių navikų pasiskirstymas pagal stadijas

\begin{tabular}{|l|c|c|}
\hline Stadija & Atvejų skaičius & $\begin{array}{c}\text { Procentas nuo bendro } \\
\text { skaičiaus }\end{array}$ \\
\hline I & 49 & 46,7 \\
\hline II & 38 & 36,2 \\
\hline III & 14 & 13,3 \\
\hline IV & 4 & 3,8 \\
\hline
\end{tabular}


yra nedidelis. Tai gali rodyti aukštą NVI radiologų darbo kokybę, tačiau gali būti susiję ir su dideliu iškvietimų dèl papildomų tyrimų skaičiumi vykdant AMPP Nacionaliniame vėžio institute. Iškvietimai atlikti papildomus tyrimus neaiškiais atvejais sumažina intervalinių navikų dažnị, tačiau gali būti susiję su hiperdiagnostika, nereikalingais tyrimais, apkrauna radiologus, didina programos kaštus. Ne mažiau svarbus ir intervalinių navikų suskirstymas ị kategorijas pagal tai, ar jie buvo matomi pagal AMPP atliktose mamogramose ir juos galima priskirti prie radiologo darbo klaidų, ar jie nebuvo matomi ir navikas susiformavo arba tapo matomas laikotarpiu tarp planuotų patikrų. Toks skirstymas leidžia įvertinti radiologų darbo kokybę. Deja, Lietuvoje intervaliniai krūtų navikai - vienas svarbiausių rodiklių, leidžiančių ịvertinti atrankinès mamografinès patikros programos jautrumą, o kartu jos organizavimo bei radiologų darbo kokybę, nèra vertinamas. O juk pagal ES rekomendacijas tai yra būtinas atrankinès mamografinès patikros programos vertinimo kriterijus [4]. Kadangi NVI nèra kaupiami pagal programą atliktų mamogramų vaizdai, radiologai neturèjo galimybès peržiūrèti ankstesnių mamogramų, suklasifikuoti navikų i tikruosius intervalinius bei klaidingai neigiamus. Taigi liko neįvertinta radiologų darbo kokybė bei neatlikta detalesnè analizè, kodèl nebuvo nustatyta ryšio tarp intervalinių navikų skaičiaus ir krūties audinio tankumo. Turime neužmiršti, kad dauguma autorių kaip vieną svarbiausių mamografinio tyrimo jautrumą ribojančių veiksnių nurodo didelį krūties audinio tankumą, o tai tiesiogiai koreliuoja su intervaliniu navikų dažniu [14-19]. Šis tyrimas - tai pirmas bandymas atlikti intervalinių navikų skaičiavimą AMPP vykdymo metu.

Mūsų atliktas tyrimas leidžia suabejoti, ar AMPP Lietuvoje naudojama pagal paskirti. Yra atvejų, kai moterys, turinčios anksčiau diagnozuotą krūties naviką, buvo atsiunčiamos tirtis pagal AMPP. Dažniausia to priežastis yra ilga vizito pas gydytoją onkologą laukimo trukmé, o mamogramos pagal programą moterims atliekamos labai greitai.

Programos metu nustatytų navikų pasiskirstymas pagal stadiją irgi leidžia manyti, kad AMPP naudojama ne pagal paskirtị. Pagrindinis programos efektyvumo kriterijus mirtingumo nuo krūties vėžio sumažèjimas, tačiau siekiant anksčiau įvertinti, ar vykdoma programa efektyvi ir ar bus pasiektas pagrindinis tikslas, yra nustatyta keletas pagalbinių rodiklių, kurių vertinimas AMPP vykdymo metu pagal ES rekomendacijas privalomas. Vienas tokių rodiklių, - AMPP vykdymo metu nustatytų navikų stadija. ES rekomendacijose nurodoma, kad 75 \% navikų turètų būti nustatomi I stadijos. Mūsų tyrimas rodo, kad I stadijos aptikta tik 49 \% navikų. NVI nustatytas navikų pasiskirstymas pagal stadijas mažai skyrèsi nuo pasiskirstymo bendrojoje populiacijoje. 2012 m. Lietuvos vėžio registro duomenimis, I stadijos krūties navikai sudare $31,1 \%$, II stadijos - 36,0\%, III stadijos - 19,5 $\%$, IV stadijos - 6,9\% [20]. Taigi AMPP vykdymo metu tik nežymiai didesnè dalis navikų aptikta I-II stadijos, palyginti su bendrais populiacijos rodikliais. Mūsų tyrimo duomenimis, net $19 \%$ navikų nustatyti pažengusios stadijos (III-IV stadijos). Tai yra tie atvejai, kai pakitimai yra akivaizdžiai matomi arba užčiuopiami ir pati moteris turi skundų. Nagrinėjant šių moterų ambulatorines korteles buvo nustatyta, kad neretai pagal AMPP tikrintis siunčiamos moterys, turinčios aiškiai užčiuopiamą naviką ar kitų krūties vėžio požymių: krūties deformaciją, išopejimą, kraujingų išskyrų. Tokios moterys po pirminès šeimos gydytojo apžiūros turètų iškart pakliūti pas krūtų ligų specialistą, nes pakitimai akivaizdūs. Anksčiau NVI atlikto tyrimo metu vertinant NVI vykdomą AMPP, buvo išanalizuoti iškviestų pagal programą dèl galbūt piktybinių ir piktybinių pokyčių mamogramose moterų duomenys 2006-2011 metais [21]. Minimo tyrimo metu buvo konstatuota, kad ị programą buvo siųstos moterys, turinčios išopejjusius navikus, akivaizdžiai matomus ar krūti deformuojančius navikus. $1 \%$ sudare T3 navikai ir $1 \%$ T4b navikai, kurie turejjo būti iš karto nustatyti po pirminès šeimos gydytojo apžiūros, o pacientès atsiųstos konsultuoti onkologui. Buvo operuoti net $8 \mathrm{~cm}$ augliai arba krūties odą infiltravę kraujuojantys navikai. Net $35 \%$ atvejų nustatytos metastazès pažasties limfmazgiuose.

Radiologų atliktas atrankinių mamogramų vertinimas pagal BIRADS atitinka literatūroje nurodomus dažnius [22]. Šiek tiek skiriasi navikų diagnozavimo dažnis nustačius BIRADS 5 kategoriją. Literatūroje nurodoma, kad, ịvertinus mamogramoje matomus pokyčius kaip BIRADS 5 kategorijos, krūties vėžio nustatymo dažnis siekia 95 \% [23,24]. Mūsų tyrimo metu dažnis siekė 86 \%. Tačiau mažesnis dažnis gali būti paaiškintas. Analizuojant duomenis buvo pastebèta keletas atvejų, kai nors visos moterys, nustačius joms piktybinius pakitimus mamogramoje, kviečiamos atvykti atlikti papildomų tyrimų, tačiau iš jų kasmet 1 ar 2 moterys neatvyksta. Vèliau jos dèl atsiradusių krūties vėžio simptomų kreipiasi i onkologus savarankiškai, tačiau praejjus ilgesniam laikui. Jei naviko diagnozė patvirtinama praejus daugiau kaip 24 mèn. po mamogramos pagal AMPP atlikimo, toks navikas lieka nepatvirtintas AMPP metu. Ivertinimas BIRADS 5 informacineje sistemoje lieka, bet naviko diagnozè laikoma nepatvirtinta.

NVI kasmet pagal programą ištiriama 8,5 \% visų Lietuvos moterų. Todèl manome, kad mūsų rezultatai gerai atspindi visos Lietuvos situaciją. Informacinès sistemos Sveidra duomenimis, $2016 \mathrm{~m}$. sausio $1 \mathrm{~d}$. PAASPI užregistruota daugiau nei 451 tūkst. nuo 50 iki 70 metų amžiaus moterų. Šios moterys ir sudaro tikslinę populiaciją, kuriai mamogramos pagal AMPP turètų būti atliekamos kas 2 metus. TLK 
duomenimis, penkto AMPP ciklo metu (nuo 2013 spalio 2 iki 2015 spalio 1 d.) užregistruota 493455 tūkst. tikslinio amžiaus moterų, ištirtos 187027 moterys, tai sudaro tik 37,9 $\%$ tikslinio amžiaus moterų. Pagal ES rekomendacijas rekomenduojama, kad vykdant atrankinę mamografinę patikrą pasitikrintų $80 \%$ moterų. Oportunistinè, necentralizuotai vykdoma atrankinè patikra nepasiekia pagrindinio savo tikslo - nesumažina mirtingumo. Nors ES rekomendacijose aiškiai nurodoma, kad moterys dalyvauti programoje turi būti kviečiamos centralizuotai, kad turi būti sukurtas programos registras ir kvietimų sistema, Lietuva lieka viena iš trijų valstybių ES, kur ši sistema vis dar nėra sukurta [25]. Mūsų turimi duomenys rodo, kad mirtingumas nuo krūties věžio Lietuvoje nemažèja [26] ir viena galimų to priežasčių - netinkamai organizuota AMPP. Situaciją apsunkina ir tai, kad Lietuvoje nesukurta AMPP efektyvumo vertinimo sistema pagal ES rekomendacijas ir nèra vertinami kiti labai svarbūs rodikliai (techniniai mamogramų parametrai, technologų darbo kokybè, papildomų tyrimų dažnis, biopsijų skaičius nustačius įtartinus pakitimus mamogramose bei biopsijų skaičius, kai piktybinio naviko diagnozė nepasitvirtino, koks taikytas gydymas nustačius krūties věžị ir t.t.), kurie būtini siekiant ịvertinti programos eigą bei efektyvumą.

\section{Išvados}

1. 2006-2012 metais NVI atliekant mamografinius tyrimus pagal Lietuvoje vykdomą AMPP nustatytas intervalinių navikų dažnis buvo 0,19 . Nedidelis intervalinių navikų skaičius gali būti siejamas su gera NVI radiologų ir radiologijos technikų darbo kokybe ir su iškvietimais atlikti papildomus tyrimus esant neaiškiems atvejams.

2. NVI vykdomos AMPP metu $19 \%$ navikų nustatomi pažengusios stadijos ir tik $46 \%$ pirmos stadijos, kai pastaroji navikų dalis tinkamai vykdant patikrą turètų siekti $75 \%$.

3. NVI sukauptų duomenų analizè parodè, kad mamografinè patikra ne visada naudojama pagal paskirti - pasitikrinti pagal AMPP neretai siunčiamos gydytos dèl krūties věžio ar akivaizdžių krūties simptomų turinčios moterys.

\section{Literatūra}

1. Day NE, Walter SD, Tabar L, Fagerberg CJG, Collette HJA. The sensitivity and lead time of breast cancer screening: a comparison of the results of different studies. In Screening for Breast Cancer. Edited by Day NE, Miller AB. Toronto: Hans Huber Publishers, 1988:105-109.

2. Fletcher SW, Elmore JG. Clinical practice: mammographic screening for breast cancer. The New England Journal of Medicine 2003;348:1672-1680. https://doi.org/10.1056/NEJMcp021804

3. Day NE, Williams DRR, Khaw KT. Breast cancer screening programmes: the development of a monitoring and evaluation system. British Journal of Cancer 1989;59:954-958.

https://doi.org/10.1038/bjc.1989.203

4. Perry N, Broeders M, de Wolf C, Tornberg S, Holland R, von Karsa L, editors. European guidelines for quality assurance in breast cancer screening and diagnosis. Luxembourg: Office for Official Publications of the European Communities, 2006.

5. Anttila A, Lonnberg S, Ponti A, Suonio E, Villain P, Coebergh JW, von Karsa L. Towards better implementation of cancer screening in Europe through improved monitoring and evaluation and greater engagement of cancer registries. European Journal of Cancer 2015;51:241-251.

https://doi.org/10.1016/j.ejca.2014.10.022

6. Parkin DM. The role of cancer registries in cancer control. International Journal of Clinical Oncology 2008;13:102-111. https://doi.org/10.1007/s10147-008-0762-6

7. Lietuvos Respublikos sveikatos apsaugos ministro $2005 \mathrm{~m}$. gruodžio 23 d. ịsakymas Nr. V-729 "Dèl atrankinès mamografinès patikros dèl krūties vèžio finansavimo programos patvirtinimo". Žin. 2005;117-4249.

8. TLK duomenys. Prieiga: http://www.vlk.lt/veikla/veiklossritys/prevencines-programos/kruties-vezio-ankstyvosios-diagnostikos-programa

9. American College of Radiology: Illustrated breast imaging reporting and data system Reston, VA: American College of Radiology, 1998.

10. Lietuvos Respublikos sveikatos ministro $2004 \mathrm{~m}$.gruodžio10 d. įsakymas Nr. V-901 "Dẻl atrankinès moterų mamografinès patikros programos atlikimo metodikos patvirtinimo" Žin. 2004;184-6815.

11. Andersen SB, Tornberg S, Lynge E, Euler-Chelpin MV, Njor SH. A simple way to measure the burden of interval cancers in breast cancer screening. BMC Cancer 2014; 14:782.

https://doi.org/10.1186/1471-2407-14-782

12. NHS Breast Screening Radiologists Quality Assurance Committee. Quality Assurance Guidelines for Breast Cancer Screening Radiology. NHSBSP Publications: Sheffield, 2005.

13. Tornberg S, Kemetli L, Ascunce N, Hofvind S, Anttila A, Seradour B. et al. A pooled analysis of interval cancer rates in six European countries. European Journal of Cancer Pevention 2010;19(2):87-93. https://doi.org/10.1097/CEJ.0b013e32833548ed

14. Vachon CM, Kuni CC, Anderson K. Association of mammographically defined percent breast density with epidemiologic risk factors for breast cancer (United States). Cancer Causes Control 2000;11:653-662.

https://doi.org/10.1023/A:1008926607428

15. Kavanagh AM, Byrnes GB, Nickson C, Cawson JN, Giles CG, Hopper JL. et al. Using mammographic density to improve breast cancer screening outcomes. Cancer epidemiology, biomarkers and pevention, 2008;17:2818-2820.

https://doi.org/10.1158/1055-9965.EPI-07-2835 
16. Kavanagh AM, Mitchell H, Giles GG. Hormone replacement therapy and accuracy of mammographic screening. Lancet 2000;355:270-274. https://doi.org/10.1016/S0140-6736(99)07319-5

17. Sala E, Warren R, McCann J, Duffy S, Day N, Luben R. Mammographic parenchymal patterns and mode of detection: implications for the breast screening programme. Journal of Medical Screening 1998; 5:207-212.

https://doi.org/10.1136/jms.5.4.207

18. Banks E, Reeves G, Beral V, Bull D, Crossley B, Simmonds $M$. et al. Influence of personal characteristics of individual women on sensitivity and specificity of mammography in the Million Women Study: cohort study. British Medical Journal 2004; 329:477.

https://doi.org/10.1136/bmj.329.7464.477

19. Carney PA, Miglioretti DL, Yankaskas BC, Kerlikowske K, Rosenberg R, Rutter CM. et al. Individual and combined effects of age, breast density, and hormone replacement therapy use on the accuracy of screening mammography. Annals of Internal Medicine 2003; 138:168-175.

https://doi.org/10.7326/0003-4819-138-3-200302040-00008

20. Vėžys Lietuvoje 2012 m. Prieiga: http://www.nvi.lt/index. php?1014526156.

21. Gudaviciene D, Briediene R, Skaisgiryte A, Kanopiene D, Steponaviciene L, Sniriene R, Obzigailovas J. Breast cancer screening results in Institute of Oncology, Vilnius University, Lithuania. The Breast, 2013; 22S1:S36.

22. Eberl MM, Fox CH, Edge SB, Carter CA, Mahoney MC. BIRADS classification for management of abnormal mammograms. The Journal of the American Board of Family Medicine 2006; 19(2):161-164. https://doi.org/10.3122/jabfm.19.2.161

23. Lacquement MA, Mitchell D, Hollingsworth AB. Positive predictive value of the Breast Imaging Reporting and Data System. Journal of the American College of Surgeons 1999; 189:34-40.

https://doi.org/10.1016/S1072-7515(99)00080-0

24. Orel SG, Kay N, Reynolds C, Sullivan DC. BIRADS categorization as a predictor of malignancy. Radiology 1999;211:845850 .

https://doi.org/10.1148/radiology.211.3.r99jn31845

25. Cancer Screening in the EU: 2nd Report on the Implementation of the Council Recommendation. Prieiga: https://ec.europa.eu/ health/major_chronic_diseases/publications_en. Accessed 23 April 2017.
26. L. Steponaviciene, G. Smailyte, R. Briediene, D. Gudaviciene. Opportunistic screening does not improve early breast cancer (BC) detection and does not reduce BC mortality. The Breast, 2017; 32S1:S54

\section{MAMMOGRAPHY SCREENING PROGRAM. EXPERIENCE AT THE NATIONAL CANCER INSTITUTE \\ L. Steponavičienė, R. Briedienė, S. Šenbergè, D. Gudavičienè, G. Smailytė}

Key words: breast cancer, mammography, early diagnostics, mammography screening program, interval cancers.

Summary

Mammography screening program (MSP) is intended for early breast cancer detection, before the disease symptoms appear and the effectiveness of the specific treatment could be maximized. It has been determined that mortality using screening mammograms can decrease by $20-35 \%$. Although the benefits of mammograms performed under the screening program are evident, no less important is the continuous monitoring of the implementation of the program since its inception. So far, no detailed work has been done to assess the process and effectiveness of MSP in Lithuania.

The purpose of this article is to summarize the performance experience and the most commonly encountered problems in the implementation of MSP at the National Cancer Institute (NCI), which is one of the largest centers providing and evaluating screening mammograms; and to assess the main indicators of current program.

In this study, a retrospective analysis of data was performed. The data of mammograms carried out by the NCI in 2006-2016 under MSP was evaluated. The dynamics of the performance and evaluation of mammograms, the number of additional studies performed, the number of malignant tumors detected, and the distribution by stage was studied. Separate analysis of interval cancers was carried out.

Our analysis of the data collected at the NCI showed that screening mammograms were not always used for their intended purpose - checking by MSP was often referred to women, who have been treated for breast cancer or with clear breast cancer symptoms. During program execution at NCI even $19 \%$ of the tumors were detected in advanced stages and only $46 \%$ of the first stage, which does not meet the program's implementation guidelines.

Correspondence to: laura.steponaviciene@nvi.lt

Gauta 2017-11-21 